\title{
Pesquisa Florestal Brasileira
}

Brazilian Journal of Forestry Research

http://pfb.cnpf.embrapa.br/pfb/

\section{Criteria to be considered to achieve a sustainable second cycle in Amazon Forest}

\author{
Evaldo Muñoz Braz¹, Patrícia Póvoa de Mattos ${ }^{1}$, Fábio Thaines ${ }^{2}$, Luc Durrieu de Madron², Marilice Cordeiro Garrastazu \\ Aline Canetti ${ }^{4}$, Marcus Vinício Neves d'Oliveira ${ }^{5}$ \\ ${ }^{1}$ Embrapa Florestas, Estrada da Ribeira Km 111, C. P. 319, CEP 83411-000, Colombo, PR, Brazil \\ ${ }^{2}$ Tecman, Rua Luiz Zacarias da Silva, 601, Estação Experimental, CEP 69912-620, Rio Branco, AC, Brazil \\ ${ }^{3}$ Free lance, Route de pranlary 43750 Vals pres le Puy, France \\ ${ }^{4}$ Universidade Federal do Paraná, Av. Pref. Lothario Meissner, 900, CEP 80210-170, Curitiba, PR, Brazil \\ ${ }^{5}$ Embrapa Acre, Rodovia BR-364, km 14, C. P. 321, CEP 69908-970, Rio Branco, AC, Brazil
}

"Autor correspondente:

evaldo.braz@embrapa.br

Termos para indexação:

Cedrela odorata

Manejo florestal sustentável

Taxa de corte

Floresta tropical

Recuperação em volume

Estrutura diamétrica

Index terms:

Cedrela odorata

Sustainable forest management

Cut rate

Rain Forest

Volume recover

Diametric structure

\section{Histórico do artigo:}

Recebido em 29 jun 2015

Aprovado em 15 set 2015

Publicado em 30 set 2015

doi: 10.4336/2015.pfb.35.83.941
Abstract - Remnant forest structure and increment by diameter class play a decisive role in the recovery volume for the next cutting cycle. Tree species in the Amazon Forest do not present a defined pattern of diameter structure, which is discussed here using Cedrela odorata L. as a case study. The aim of this study was to identify, by simulation, recovery from logging in a real situation at three timber production sites, and the alternatives that are available to ensure commercial timber volume to a second cut cycle in Brazilian Amazon. The study is concerns the diametric classes of productive trees to the next cycle. The comparison demonstrates that one of the strategies recovers stock volume more quickly than expected in the cut cycle defined by Brazilian law. The number of trees remaining at the sites does not corroborate the common assumption that forest management depletes large diameter trees. This paper presents assessment strategies to evaluate and establish the diametric structure that would enable the possible recovery in the second cut cycle, depending on the volume logged during the first cut cycle.

\section{Critérios para a sustentabilidade do segundo ciclo em Floresta Amazônica}

Resumo - Estrutura da floresta remanescente e o incremento por classe de diâmetro desempenha papel decisivo na recuperação do volume para o próximo ciclo de corte. Espécies de árvores na Floresta Amazônica, não apresentam um padrão definido de estrutura de diâmetro, discutido aqui utilizando Cedrela odorata L. como estudo de caso. Os objetivos deste trabalho foram identificar, por meio de simulação, a recuperação florestal após o manejo em uma situação real em três locais de produção de madeira, e as alternativas disponíveis para assegurar a recuperação do volume comercial de madeira em um segundo ciclo de corte na Amazônia brasileira. $\mathrm{O}$ trabalho se refere às classes de diâmetro de árvores produtivas para o próximo ciclo. A comparação indica que uma das estratégias usadas permite recuperar o estoque de volume mais rápido do que o tempo definido no ciclo de corte estabelecido em lei. O número de árvores remanescentes nos locais não corrobora a suposição comum de que o manejo florestal esgota árvores de grandes diâmetros. Este artigo apresenta estratégias de levantamento para avaliar e estabelecer a estrutura diamétrica mais indicada para recuperar no segundo ciclo o volume registrado durante o primeiro ciclo de corte. 


\section{Introduction}

Despite the efforts of regulatory institutions, timber forest management in the Brazilian Amazon rainforest continues to be carried out without planning for future cut cycles. Wood production, based on studies of growth and income, has not been effectively practiced (Oliveira, 2009), although there have been proposals made to include it in Brazilian Amazon area management plans (Schöngarten, 2008; Braz et al., 2014) and in the Bolivian Amazon area (Brienen \& Zuidema, 2006b).

Annual cut rates are not usually based on forest structure data tree species growth rhythm (Putz et al., 2000). Moreover, the forest re-growth is dependent on the remnant forest structure (Braz et al., 2012a, 2012b). At present, none of this technical information is being considered in the development of management plans. It is therefore clear that there is considerable gap for improving the effective management of natural tropical forests.

The resilience of rainforest during cutting cycles is frequently questioned (Van Gardingen et al., 2006; Sist \& Ferreira, 2007; Azevedo et al., 2008), but the effects of alternative management strategies on the remnant structures have not yet been properly analyzed. These analyses are based on arbitrary logging, which is often incompatible with the tree cycle and with the growth dynamics of the species. Moreover, the analysis of sustainable forest management are often carried out without considering the logging companies procedures and the characteristics of the species distribution at different sites. It is clear that the question is not whether arbitrary extraction is sustainable, but which strategies are viable to make sustainable logging possible. Putz et al. (2012) indicated that if using cut cycles of 20-40 years, logging intensities should be reduced, but it would imply a reduction in profits.

Decision makers in the Brazilian Amazon region are still not included in the discussion about cut rates, as they do not have practical simulation models available. Many complex models have been discussed and priorities have been elected, but they remain as black boxes in researcher's domain.

Alder (1992) considers complex simulation models as "esoteric entities" in which the decision maker can accept or reject entirely, and often the available data do not justify these models. For example, the model SYMFOR (Silviculture and Yield Management for Tropical Forests) is useful to evaluate the forest dynamics in primary forests, but for different scenarios of forest under management the model shows divergent values from actual results of surveys (Azevedo et al., 2008). Moreover, Clutter (1980) considered that stochastic models might be less accurate than deterministic models and that greater efforts to generate more easily applicable solutions are required. Porté \& Bartelink (2002) consider that stand level simulations fit the yield data better than the tree level simulation. They also consider 50 years as a short-term prediction, and 100 years as long-term. Simple models may be the best compromise between no implementation of effective forest management and the uncertain and piecemeal application of more sophisticated models (Alder, 1992). Vanclay (1994) considers the models of projection by size class diameter can still be useful when data are scarce. Braz et al. (2012) identified the percentage of contribution of each diameter class to compose the commercial wood volume, emphasizing that when the differentiated increment of each class was not considered, the final forest production could be compromised.

Forest management that considers the total group of species to be managed without individualizing the recovery potential of each species drastically reduces the possibility of a new economic cycle when working in a poor forest. On the other hand, it may underestimate recovery when managing a rich forest and impair planning in terms of timber production.

In Brazil, a limit of $30 \mathrm{~m}^{3} \mathrm{ha}^{-1}$ is applied for all species. This is considered to be a low cut rate and is applied regardless of the species growth rhythm. The cut cycle, in accordance with this legislation has varied arbitrarily from 25 to 35 years over the last 7 years. The argument is that logging should be low enough to make possible the recovery in a cut cycle and ensure "sustainability". However, the forests in the States of Acre, Para, Amazonas and the northern areas of Mato Grosso show different potential (diameter increment and species diversity) from other parts of the managed forest. According to Amaro (1996), Cedrela odorata L. occurred in 8 of the 13 different forest types (95.8\% of the inventoried area) that were described along the $500 \mathrm{~km}$ of the BR-364 road, which crosses the state of Acre. Braz et al. (2011) also highlighted that $C$. odorata presents a different diameter structure when compared with a different $C$. odorata population stock. Therefore, it is inappropriate to manage these areas in the same way as other regions of the forest. 
This study is directed towards timber production sustainability and, where possible, the study can provide information on management support to reach ecosystem sustainability. The aim of this study was to identify by simulation the recovery of using current logging methods, used by timber enterprises in three timber production sites, and alternatives available to ensure commercial timber volume to a second cut cycle, while simultaneously aim to improve future sustainability. Analysis procedures were also presented, concluding that generalized rules for Amazonian forests may cause management errors. The suggested analysis procedure of recovery capacity aims to support decision makers in the Amazon region in the form of an accessible tool to allow them to take part in forest management discussions.

\section{Material and methods}

\section{Characterization of the studying area}

Three forest stands were selected to implement forest management in the state of Acre. The trees to be cut in the second cycle, the remaining trees and the permanent preservation areas (PPA) were determined according to the forest management plan approved for each area.

The climate of the region is Am, with warm and humid monsoons (Köppen, 1936). The mean air temperature in the three areas ranges between $24.5^{\circ} \mathrm{C}$ and $25.5^{\circ} \mathrm{C}$. The mean temperature of the coldest month (July) and the hottest month (October) is $23.3{ }^{\circ} \mathrm{C}$ and $25.8{ }^{\circ} \mathrm{C}$, respectively. The relative air humidity is $85 \%$ and annual rainfall ranges from $1,600 \mathrm{~mm}$ year ${ }^{-1}$ to $2,750 \mathrm{~mm}$ year ${ }^{-1}$.

Stand 1 (993 ha): It is located south of Sena Madureira County. The soil from stand 1 is predominantly Typical Plinthustalfs and Rhodic Kandiudults. The area is located in the Iaco River Basin and around other small streams, which are tributaries of the Purus River. The relief varies from soft to strong slopes. The vegetation is predominantly Open Rain Forest according to the Ecological-Economic Zoning of Acre (Acre, 2006). The area presents a water deficit with withdrawal of ground water occurring from May to September. The water renovation occurs from September to November.

Stand 2 (993 ha): It is located in the middle region of the Acre River Basin, in Capixaba County. The stand site presents predominantly Rhodic Kandiudults soils, accounting for more than $80 \%$ of the area. The topography is almost flat, with few and sparse slopes that are not involved in the logging activities. In a small portion there is an undulating slope (Acre, 2006). The predominant forest type is Open Rain Forest with palm trees.

Stand $3(736 \mathrm{ha})$ : It is located in central region, in Feijó County. According to a pedological map and the ecological zoning studies of Acre State, there is a combination of predominant soils in the region, including Typical Hapludalfs, Typic Dystrudepts and Chromic Dystruderts soils (Acre, 2006). The region presents flat to undulating slope. The predominant forest type is Open Rain Forest with palm trees.

\section{Prognosis of forest recovery based on cut rate}

A survey of all the trees above $30 \mathrm{~cm}$ of diameter at $1.30 \mathrm{~mm}$ above soil level (DBH) (pre-logging survey or "tree census") was performed. In this survey, every tree selected to be cut was labeled, according to the company planning, as were those to be set aside. The set aside trees are those that grow in the permanent preservation areas (PPA) or those reserved as mother trees and as wood stock for the next cutting cycle

The periodic annual increment (PAI) and mortality was assessed by diameter class for the species $C$. odorata (48 trees), at an interval of ten years. The PAI was obtained by the mean values achieved by each diameter class in 40 permanent plots (PP), of one hectare each $(100 \mathrm{~m} \times 100 \mathrm{~m})$, installed in each micro-region. The trees were re-measured, to calculate the $\mathrm{PAI}_{\mathrm{dbh}}$ (periodic annual increment, in $\mathrm{DBH}$ ) as presented in equation 1.

$$
\mathrm{PAI}_{\mathrm{dbh}}=\left(\mathrm{DBH}_{\text {final }}-\mathrm{DBH}_{\text {initial }}\right) / \mathrm{t}
$$

Where $\mathrm{DBH}_{\text {final }}$ is the diameter at $1.30 \mathrm{~m}$ above soil level measured at the end of the evaluation period; $\mathrm{DBH}_{\text {initial }}$ is the diameter at $1.30 \mathrm{~m}$ above soil level measured at the beginning of the evaluate period; and $t$ is the time period, in years, between the two measurements.

Based on the observed remaining diametric structure of $C$. odorata chosen in each case, the percentage of volume recovery was evaluated, considering the selected cut rate.

The volume recovery at the 3 sites was simulated by the diameter class projection method (Alder, 1995; Scolforo, 1998), fragmented into five-years periods, using the growth increment of timber trees, recruitment and mortality in the period. The possible transition between classes was obtained based on the PAI of each class, including the mortality. Recruitment was defined based on the number of trees in the first class $(25 \mathrm{~cm}$ of $\mathrm{DBH})$ of the remnant forest structure. 
The model was calibrated and compared to the growth standard of the permanent plots, based on the 10 monitored years. The mortality $(\mathrm{M})$ rate observed in $\mathrm{PP}$ was used. Five-year periods were simulated for the next 30 years, by applying the formula:

$$
\mathrm{M}=(1-0.0 \mathrm{i})^{\mathrm{n}} \text {. }
$$

Where " $i$ " is the death rate in each class, " $n$ " is the cut cycle in years, and $\mathrm{N}$ is the number of individuals in each class.

The volume amount that each diameter class would contribute individually to the future volume (after 30 years), simulating the growth of 100 trees per class (to standardize the comparison), was calculated, in accordance with the procedure presented by Braz et al. (2011) and adapted from Alder (1995). The volume that may be reached during the considered cut cycle could be identified from each individual class. The proposed system, called "Optimization of diameter classes in natural forests" (Braz et al., 2011; 2012a) aims to determine which classes contribute most to the final volume, while considering the origin point (dbh classes before their transition to higher dbh classes). The productive $\mathrm{DBH}$ classes will indicate the DBH class thresholds that may be considered as maximum expected volume.

The following procedure was used:

- The current mean volume was verified, considering 100 trees per diameter class (V1).

- According to the class diameter increment, the potential growth volume of those 100 trees was simulated for a period of 30 years (V2), considering the mortality between classes in the period. The production is simulated individually for each class, isolating the other classes.

- In every class, V1 was subtracted from V2 to identify which class presented the most optimized upgrade path class, contributing most to the final volume at the end of the new cycle.

- C. odorata diameter distribution in each stand was evaluated to identify sustainable extractions aiming at the future production, in a 30 -year cycle.
- The potential forest capacity to recover timber production was estimated by simulating the results according to the logging plan and procedure system that is usual in the company for the studied stand structures.

- f) The evaluation of possible different remnant structures and the forest recovery potential, considering timber volume, were carried out with the company's decision maker, thereby selecting the possibilities of remnant structures that were consistent with the company's commercial needs. The goal was to seek a balance point between cut rate and recovery capability for the second cut cycle, which would determine a "maximum expected volume" of forest recovery in the simulation of the new cut rate selected.

- The theoretic mean distance among the trees was calculated as follows:

$$
d=\sqrt{\frac{A}{N}}
$$

Where $d$ is the mean distance among trees; $A$ is the total area of the stand (ha); $N$ is the number of trees before logging or number of trees after logging.

The actual distance to the nearest tree was assessed using a geographic information system (GIS).

The volume was calculated using equation 4 , which was developed for the forest in study, presented by Braz et al. (2012a) derived from Hohenadl-Krenn model (Finger, 1992):

$\mathrm{CV}=-1.21685+0.02959 * \mathrm{DBH}+0.000501 * \mathrm{DBH} 2$

Where $\mathrm{CV}$ is the commercial volume $\left(\mathrm{m}^{3}\right)$ and $\mathrm{DBH}$ the diameter $(\mathrm{cm})$ at $1.3 \mathrm{~m}$ above soil level.

The structures were evaluated according to Assmann (1970) adapted by Braz (2010), considering "restocking", "full production" and "canopy change" to identify the suitability of the concept in the structure analysis. The structures were also evaluated according to Durrieu de Madron \& Forni (1997), with the aim of comparing the recovery based on the cutting simulation by normal company procedure and simulation using the suggested cut rate (equation 5):

$$
\operatorname{Re}_{\%}=\frac{\left[N_{0}(1-\Delta)\right](1-\alpha)^{T} .100}{N_{p}}
$$


Where, $\mathrm{Re}_{\%}$ is the recovery ratio of a number of stems above the minimum cutting diameter (MCD); $\mathrm{N}_{0}$ is the number of trees from DBH classes below MCD that would reach the MCD in the period considered; $\mathrm{N}_{\mathrm{p}}$ is the number of stems above the MCD at time 0 (zero); $\alpha$ is the annual mortality rate; $T$ is the time interval considered; $\Delta$ is the damage rate due to exploration.

The diametric structures were evaluated according to the original stand sizes, to make understanding of the real effect possible. The commercial diameter was determined above $50 \mathrm{~cm}$ of $\mathrm{DBH}$, considering the $55 \mathrm{~cm} \mathrm{DBH}$ centre class and the class interval of $10 \mathrm{~cm}$.

\section{Results}

C. odorata diameter periodic increment was $0.85 \mathrm{~cm}$. year $^{-1}$, calculated as a weighted mean of trees from 15 and $115 \mathrm{~cm}$ class centre of DBH (figure 1). The diameter increment presents a typical rhythm, with a stage of minimum increment (between classes 15 and $20 \mathrm{~cm}$ of DBH), maximum increment (class of $45 \mathrm{~cm}$ of $\mathrm{DBH}$, reaching $1.26 \mathrm{~cm} . \mathrm{year}^{-1}$ ) and subsequent decrease (55 cm of DBH and higher). This tendency seems to be a pattern in natural forests and it is similar to that obtained by Brienen \& Zuidema (2006a), when studying four species from the Bolivian Amazonian forest while applying dendrochronology. Similar growth patterns were also observed by Braz (2012a), for a group of 26 species by permanent plots measurements.

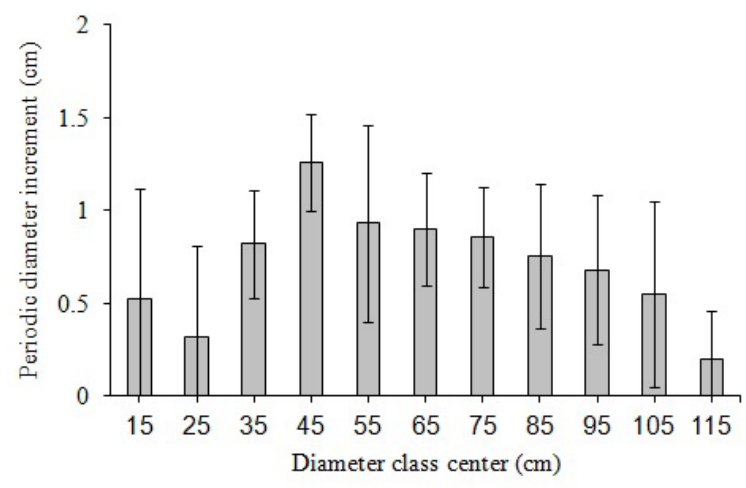

Figure 1. Diameter increment according to diameter class

The mean period of passage between classes (each class with $10 \mathrm{~cm}$ width) was 18 years, considering 11 classes. The mean passage between classes from 55 to $75 \mathrm{~cm}$ of DBH was 11.2 years. When mortality rate was disregarded, all trees from classes 35 and $45 \mathrm{~cm}$ of DBH and approximately $25 \%$ of the $25 \mathrm{~cm}$ of $\mathrm{DBH}$ class could reach a minimum commercial DBH in a 30-year cut cycle.

Figure 2 shows the volume production, considering the diameter classes remaining for the next cycle, when applying the procedure to identify productive $\mathrm{DBH}$ classes. The purpose is to identify which classes from origin (starting point of the cycle) contributed most to the final commercial volume (end of cycle), considering the class flux and discounting mortality. This makes it possible to define the limit diameter of maximum production, and also the DBH classes that do not present increment to contribute to the next cycle. In figure 2, the last class that still contributes to the volume of the future cycle is $85 \mathrm{~cm}$ of DBH, although with a very low volume. The produced volume by trees from the class equal to or higher than $95 \mathrm{~cm}$ of DBH may be negative, when compared to the volume at the beginning of the cycle. This negative result is not only a consequence of the small volume increment of the larger trees, but is also, and probably mainly, due to the mortality that occurred during the cut cycle. For C. odorata, in this studying site, trees above the class of $85 \mathrm{~cm}$ of $\mathrm{DBH}$ proportionally accumulated very little volume and did not balance with the outgrow of previous classes.

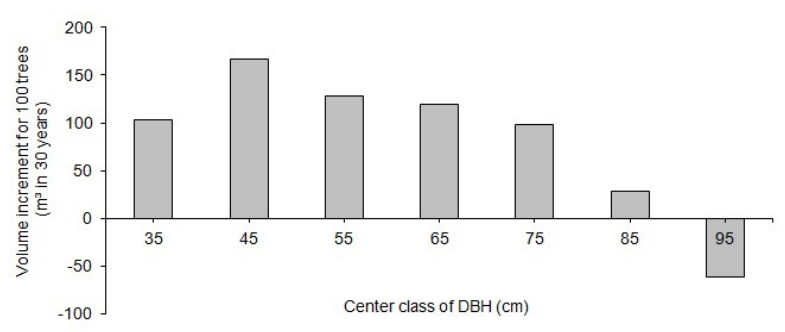

Figure 2 . Optimization of original classes considering the destination classes, calculated for 100 trees at the end of 30-year cycles.

Assuming a realistic expectation, it can be determined that the maximum sustainable timber volume that may be expected for the next cycle will be similar to currently available volume between classes that have $55-85 \mathrm{~cm}$ of $\mathrm{DBH}$, which are the classes that are commercial and that also contribute to the total volume at end of the 30year cut cycle. Above the classes of $85 \mathrm{~cm}$ of DBH the increment is too low, which results in a time passage between the classes that rises to 28 years, and which may rise to 50 years, when considering classes above $115 \mathrm{~cm}$ of DBH. Furthermore, in theory, the mean DBH increment of $0.85 \mathrm{~cm}$ year $^{-1}$ is not enough to make it 
possible for the $55 \mathrm{~cm}$ of class center to outperform the $85 \mathrm{~cm}$ of class center in a cut cycle. The high mortality beyond the $85 \mathrm{~cm}$ of class center is also an important feature $\left(2.8 \%\right.$ year $^{-1}$ after this DBH class center).

When considering all tree species from the stands (Figure 3a), it is possible to observe that the number of the sites 1 and 3 are in "full production" with 53\% and $65 \%$ of basal area (figure $3 \mathrm{~b}$ ) in the upper classes, respectively. Site 2 is clearly in "restocking", with $23 \%$ in the lower classes, $32 \%$ in the intermediate classes and $45 \%$ in the upper classes.
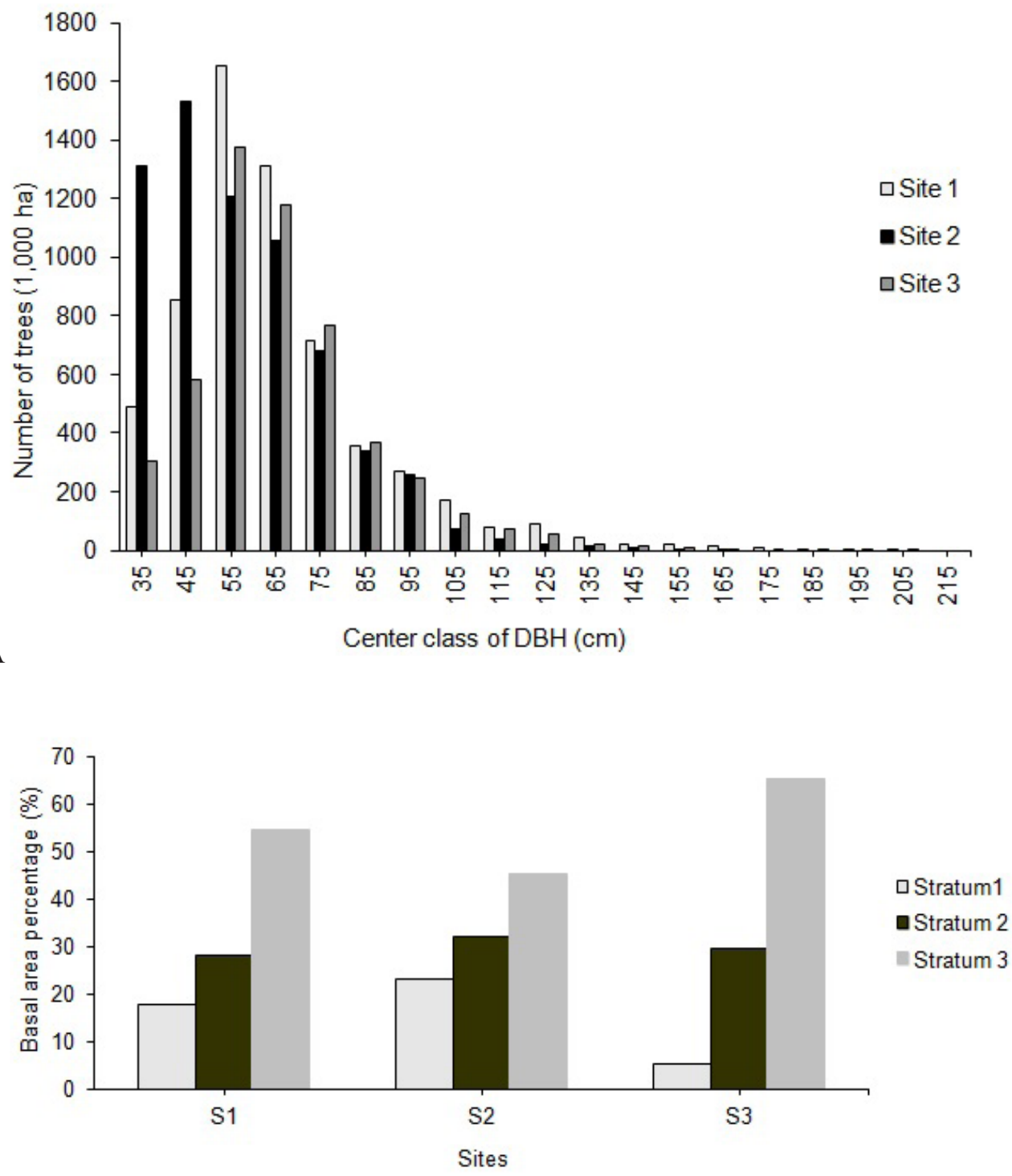

B

Figure 3. Horizontal structure (a) and basal area percentage (b) in the three studied sites areas, considering all species. 


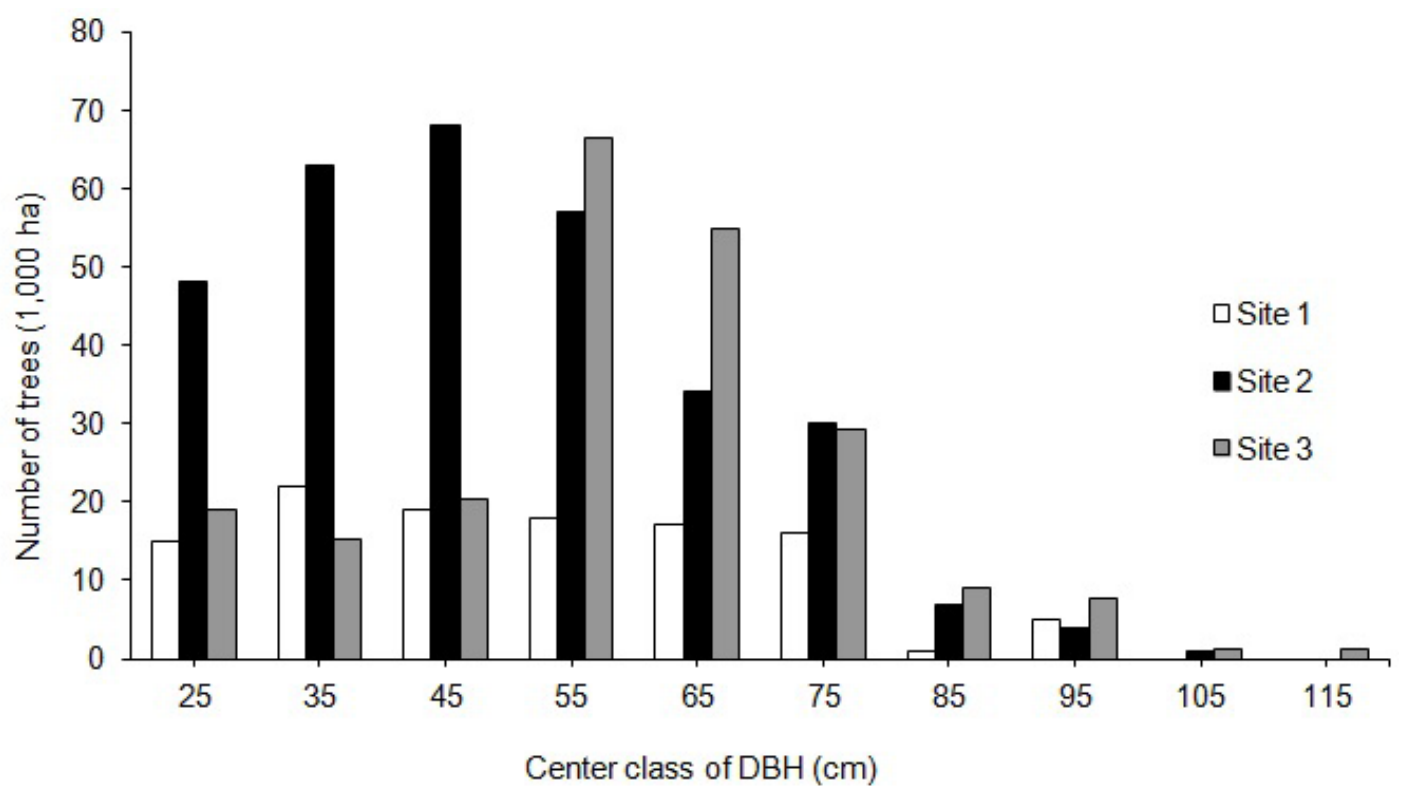

Figure 4. Diametric distribution of $C$. odorata at the three studied sites, considering an area of 1,000 hectares.

Following the same tendency, figure 4 shows that the $\mathrm{DBH}$ distribution of $C$. odorata diametric distribution is also different in the three studied sites. The number of trees by diameter class in the sites 1 and 3 also reflects a full production structure, while site 2 shows a more balanced stock in relation to the trees available for logging.

\section{Total remnant forest structure}

Timber legislation requires that logging companies set aside $10 \%$ of all trees from commercial classes as mother trees, which should be added to the remaining trees for next cycle and to the trees in the permanent preservation areas (PPAs).

Figure 5 shows that the company sets aside many more trees in the $55 \mathrm{~cm} \mathrm{DBH}$ class center than required by law, which reflects a characteristic of the Brazilian Amazon region. In addition, trees above $30 \mathrm{~cm}$ of DBH that remain in site 1 in PPAs added to the remnant trees set aside for future logging and mother trees constitute $62 \%$ of all trees above $30 \mathrm{~cm}$ of DBH on that site.
The theoretic mean distance among all the trees before logging was $258 \mathrm{~m}$. When considering the company's cutting plan to managing the entire compartment area, the mean distance would increase to $328 \mathrm{~m}$ after the simulated logging. However, at site 1, the actual mean distance among the trees, determined using GIS, increased from $123 \mathrm{~m}$ before logging, to $143 \mathrm{~m}$ after logging (Figures 5a and 6).

At site 2 , the remnant trees make up $66 \%$ of the initial population (Figures $5 \mathrm{~b}$ and 7 ). At this site, the theoretic mean distance among the trees before logging was $181 \mathrm{~m}$ and after the simulated logging it was $223 \mathrm{~m}$. At site 2 , the actual mean distance from the nearest tree ranged from $81 \mathrm{~m}$ before logging to $97 \mathrm{~m}$ after logging (Figure 7).

At site 3 (Figures $5 \mathrm{c}$ and 8 ), the number of remnant trees above $30 \mathrm{~cm}$ of DBH were $52 \%$ of total trees from the initial population, and the mean theoretic distances before and after logging changed from $178 \mathrm{~m}$ to $248 \mathrm{~m}$. The actual mean distance to the nearest tree at this site before logging was $82 \mathrm{~m}$, and $105 \mathrm{~m}$ after logging (Figure 8). 

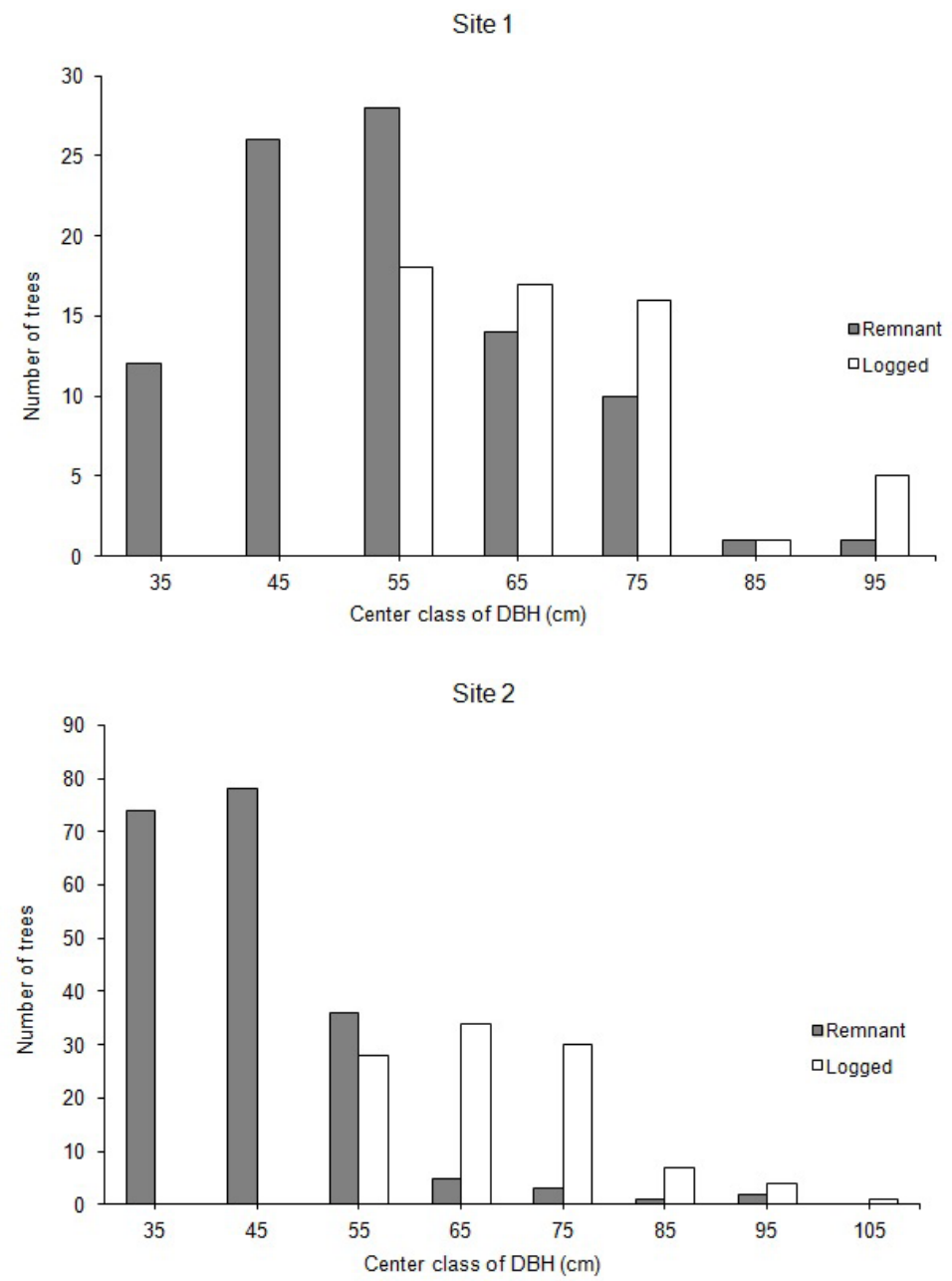

Site 3

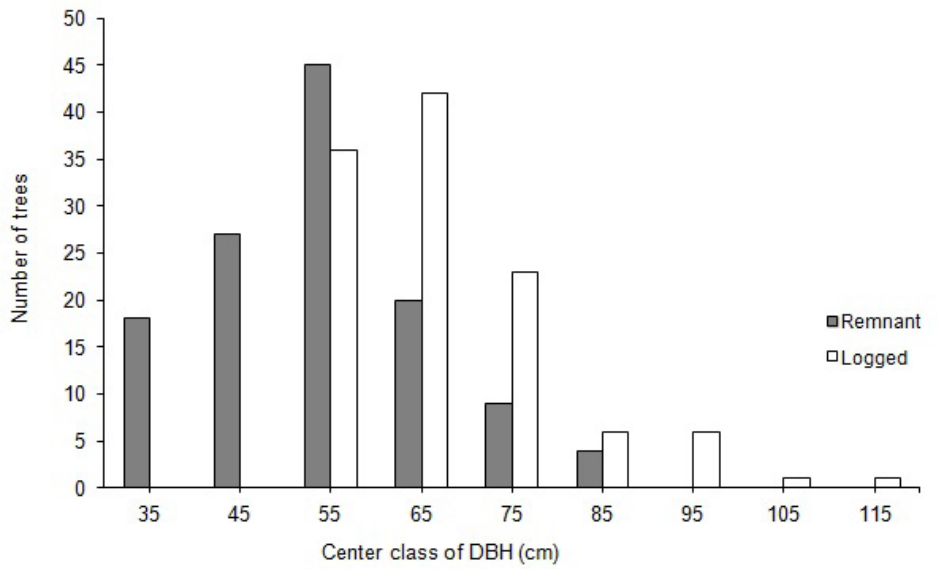

Figure 5. Remnant forest structure at the three studied sites. 


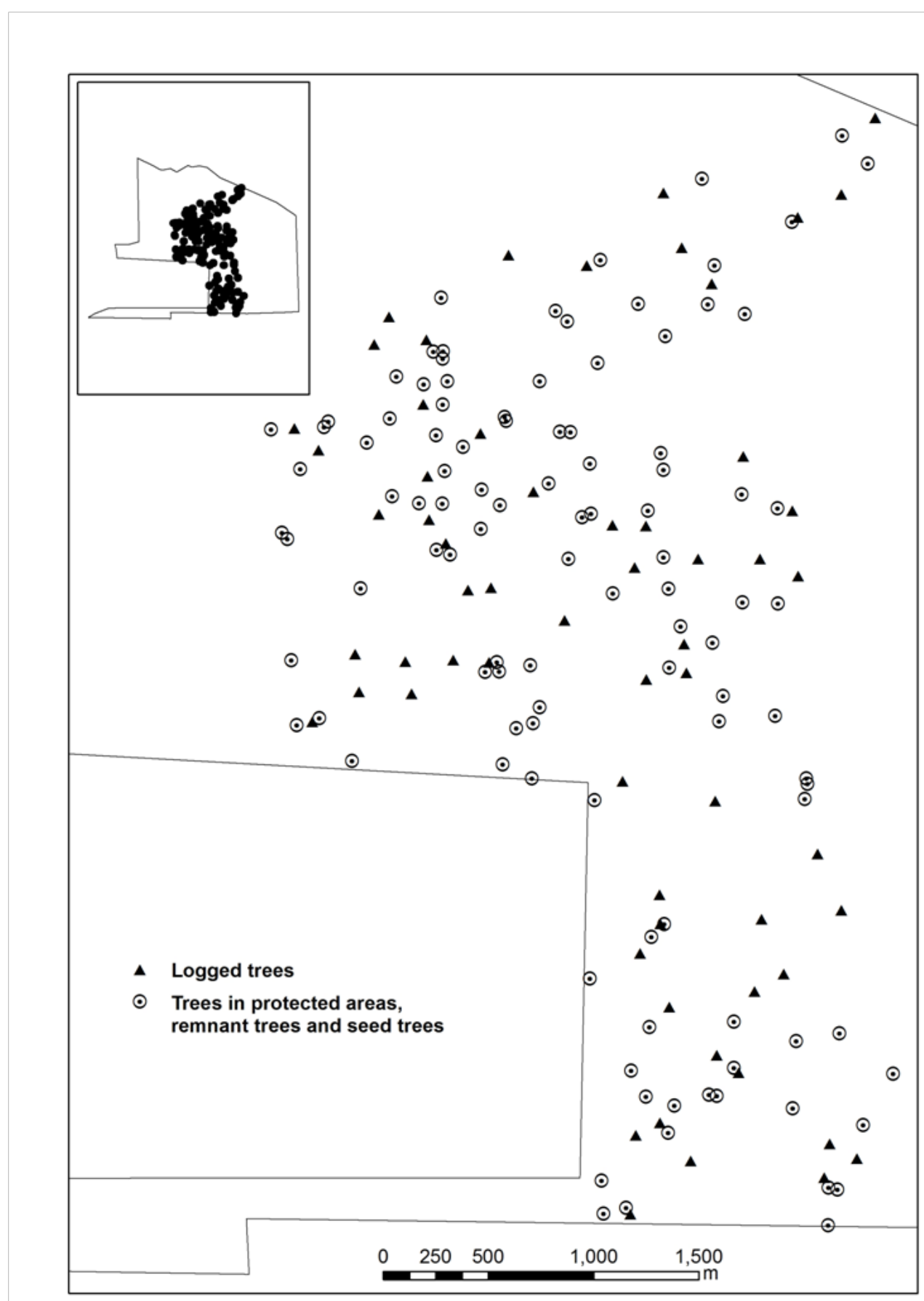

Figure 6. Tree distribution at site 1. 


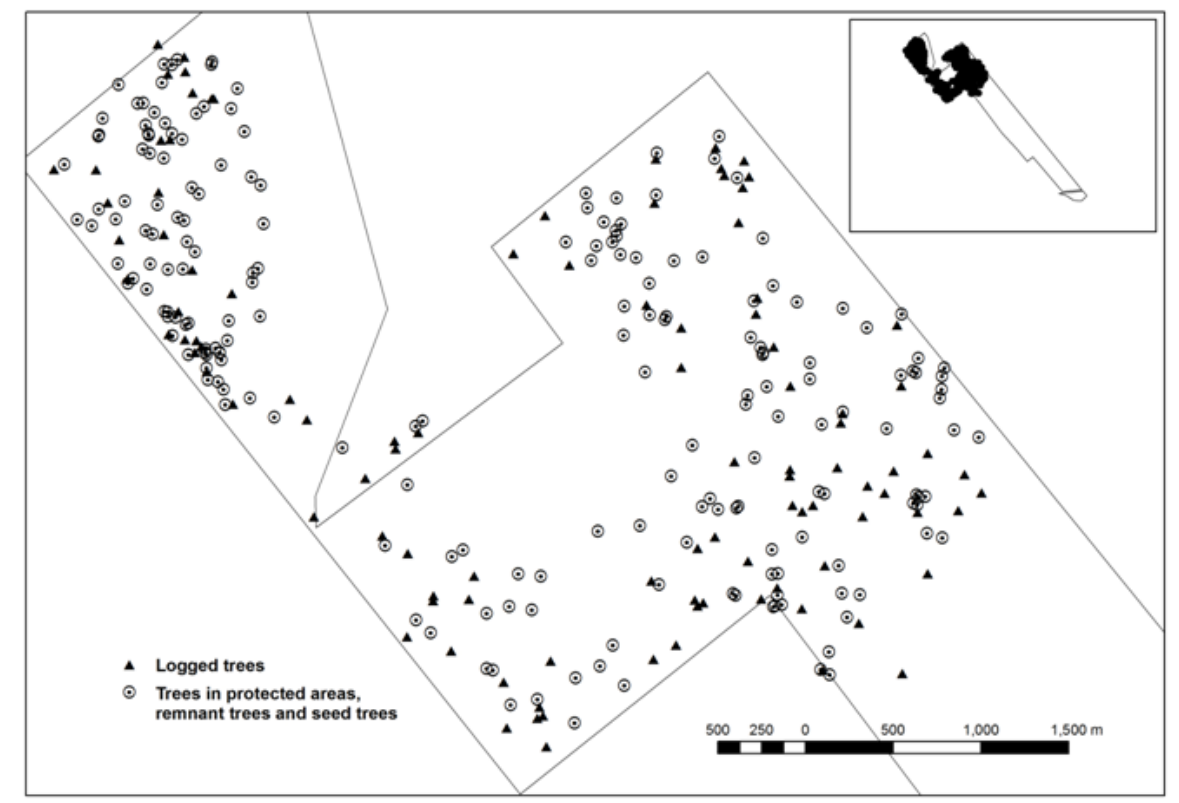

Figure 7. Tree distribution at site 2.

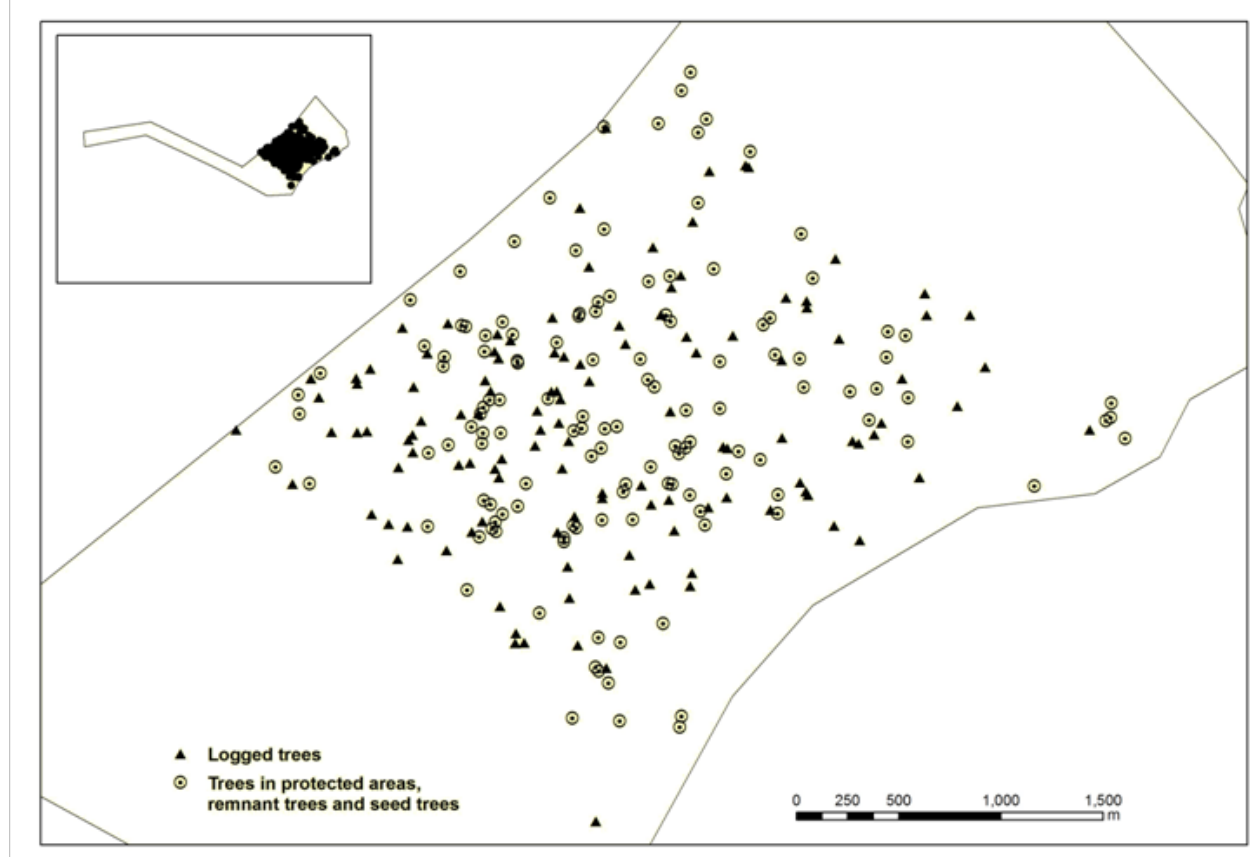

Figure 8. Tree distribution at site 3 . 
As was seen at site $1,61 \%$ of mature tree coverage remains, with $54 \%$ with DBH above $50 \mathrm{~cm}$, which is the lower diameter that cut is permited by Brazilian law, and $36 \%$ above $40 \mathrm{~cm}$ of DBH that represents the potential recruitment. Regarding site $2,66 \%$ of the coverage remains, with $15 \%$ above 50 of DBH and $41 \%$ above 40 $\mathrm{cm}$ of DBH. And at site 3,68\% of the coverage remains, with $33 \%$ above $50 \mathrm{~cm}$ of DBH and $44 \%$ above $40 \mathrm{~cm}$ of DBH.

\section{Timber production}

The following strategies were analyzed for diametric remnant distribution in order to obtain a structure that would make a second productive cycle possible.

Considering site 1 (993 ha), the useful volume of $C$. odorata is $211.0 \mathrm{~m}^{3}$. However, the company's proposed logged volume was $177.6 \mathrm{~m}^{3}$ of this species in the first cycle, representing $84 \%$ of the total commercial volume. Considering the proposed logging by the company's management, the recovery prognosis was only $108.2 \mathrm{~m}^{3}$ $(60 \%$ of the cut volume and $51 \%$ of the useful volume available). To recover this extraction rate a cycle of 37 years would be necessary. In Figure 9a, according to the previously presented concept of "maximum expected volume" (here $130 \mathrm{~m}^{3}$ ), the estimated production for the second cycle would not be reached either. In a second proposal, discussed with the decision maker of the company, it could be reduced in only $8.35 \%$ of the volume logged, representing the current proposed logging of $162.8 \mathrm{~m}^{3}$. When calculating again, considering the remnant trees, it would be possible to obtain the "maximum expected volume" for this structure, reaching a recovery of $132 \mathrm{~m}^{3}$ ( $81 \%$ of the logged stock) in 30 years. According to the analysis system proposed by Durrieu de Madron \& Forni (1997) in the company's logging plan, $60 \%$ would be recovered and, with the new proposal, it would recover $80 \%$. The theoretic mean distance among trees would increase $18 \%$.

For site 2 (993 ha), the commercial wood volume was estimated by the company at $383.7 \mathrm{~m}^{3}$. The wood volume established by the forest company to be logged was $327.8 \mathrm{~m}^{3}$, representing $86 \%$ of total commercial volume. The simulated volume recovery reached $332.0 \mathrm{~m}^{3}$. This represents $101 \%$ of the logged volume, which exceeds the logged volume and the "maximum expected volume" $\left(294.5 \mathrm{~m}^{3}\right)$. There was no need to improve this system. This shows the influence of the remnant structure pattern in the second cycle and it should be highlighted that fixed and general predictions cannot be made without careful prior evaluation (Figure $9 b)$.

It can also be observed that only after 27 years it would be possible to recover the initial volume, thus there is no need for a new proposal. According to the system from Durrieu de Madron \& Forni (1997), the recovery would reach $113 \%$ of the logged volume.

For site 3 ( $736 \mathrm{ha}$ ), the wood commercial volume was estimated by the company at $395.0 \mathrm{~m}^{3}$. The company was aiming for a production of $354.8 \mathrm{~m}^{3}(90 \%$ of total commercial volume) in this area, and the simulated recovery, considering the company logging, would only be $122.21 \mathrm{~m}^{3}$ (34\% of the logging planned by the company, and $41 \%$ of the "maximum expected volume"). To recover this extraction rate 75 years would be necessary.

So, in this case a drastic reduction of $33 \%$ in the logged volume would be necessary (Figure 9c) to obtain a recovery of $304.4 \mathrm{~m}^{3}, 102 \%$ of the "maximum expected volume $\left(299.0 \mathrm{~m}^{3}\right)$ " and $86 \%$ of the logged volume. The percentage of remnant trees would rise to $67 \%$ and increase the mean distance among trees by only $14 \%$ in this case. So, the expected volume recovery would be $304.4 \mathrm{~m}^{3}$, representing $102 \%$ of the maximum expected timber volume $\left(299 \mathrm{~m}^{3}\right)$ and $86 \%$ of the explored timber volume. On the other hand, when using the evaluation proposed by Durrieu de Madron \& Forni (1997), the management proposed by the company would recover $33 \%$ and according to the new proposition it would be possible to recover $121 \%$ of the timber volume. 


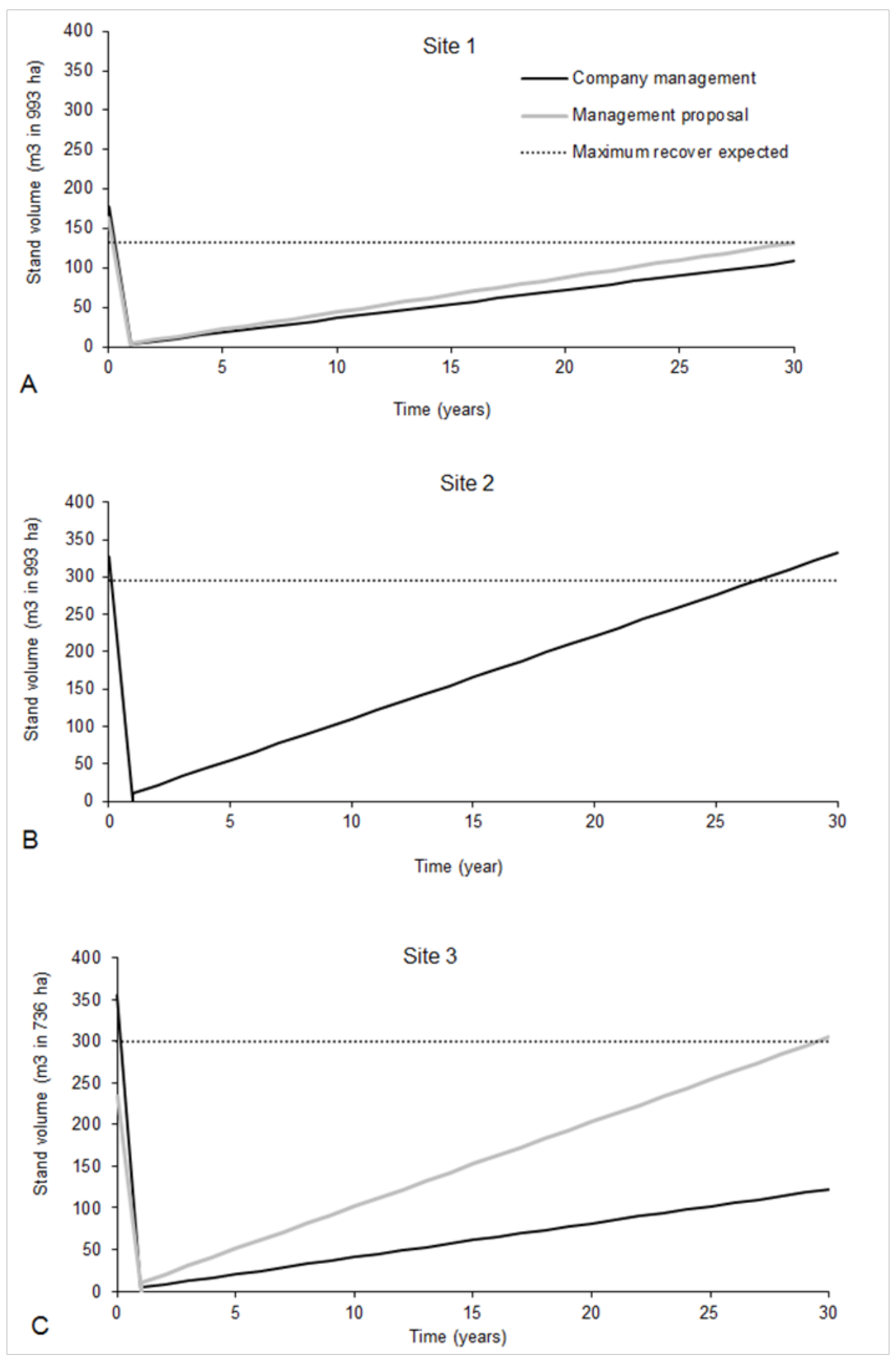

Figure 9. Company logging plan and proposed management for studied sites. 


\section{Discussion}

This paper considers the term timber production sustainability as a different approach to the ecosystem sustainability.

The diameter increment of the trees analyzed was similar to that observed by Cunha \& Finger (2013) for the same species. It was considered high, when compared to other tree species from natural tropical forests (Silva et al., 2002).

When considering the species mean diameter increment, the mean passage period between classes to C. odorata was similar to the interval period observed by Brienen \& Zuidema (2006b) in a study carried out in the Bolivian Amazon. The main difference observed was that in the Bolivian Amazon the passage interval of class $25 \mathrm{~cm} \mathrm{DBH}$ was of 11 years, compared with approximately 31 years in Acre State. In the following class the passage interval was 12 years, which is a value consistent with the growth pattern. This suggests that the trees sampled in the class of 25 mostly presented a growth restriction that is possibly due to light limitation, therefore they are suitable for silvicultural treatments, which might result in better performance and influence better volume recovery simulations. The class of 45 $\mathrm{cm} \mathrm{DBH}$ seems to be a point of maximum production and, after this DBH class center, the increment starts to reduce, even when the trees are already in the upper storey. Therefore, the DBH classes that may have their performance improved are only the ones below $45 \mathrm{DBH}$ class.

In this paper, the fact that different sites present different potential cut rates is emphasized. Many studies emphasize the lack of sustainability of Amazon forest management as a whole, without specifying that each site can produce completely different structures. A mistake that has been repeated constantly is when the analysis does not consider the different stocks of the species at different sites and the lack of compatibility with the period available for recovery. Management assessments should be carried out case by case. For example, Zimmerman \& Kormos (2012) mention that C. odorata only occurs in a structure biased towards large diameters. The cases presented showed here that the structures were different at the three studied sites, which contrasts with such a generalization. Braz et al. (2011) presented three other areas with $C$. odorata, two in the state of Acre and a third one in Amazonas State, which also had different weights on diameter structure. In the study by Brienen \& Zuidema (2006a), it was also shown that $C$. odorata had a diameter distribution with a greater number of trees in the smaller classes.

On the other hand, the concepts of "restocking" and "full production" were adequate to analyze the structures in natural Amazon forests. It should be noticed that the total group of species and C. odorata showed the same distinctive feature at the 3 sites (Figure 9), confirming that site 2 is more resilient as a whole. This shows that this is not an isolated tendency of $C$. odorata itself, but a site tendency. This endorses the impossibility of simplifying the structures as only one type, by applying mean values, because they have different site conditions.

For $C$. odorata specifically, site 1 was in "full production", but with low volume when compared to the other sites. Site 2 presented "restocking", as the stock was sufficient to recover the logged timber. Finally, site 3 was in a stage above "full production", making it difficult to adequate the low stock to the large volume of available logging timber in the first cut. Moreover, this can have a negative influence on regeneration. Thus, a phase of "restocking", paradoxically, having less volume available for logging, and more in stocking, will have a cut rate that is more feasible for recovery.

At sites 1 and 3, it was possible to plan the remnant structure aiming at a larger volume for the next cycle. Evidently, as it is a timber production area, the sustainability related to economic factors is very important, and the final decision to use this alternative should be taken by the company. Regarding site 1, the first recovery period of 37 years was easily reduced to 30 years. At site 2, the recovery would occur within a 30year cycle. Moreover, the need for 75 years to recover at site 3 , considering the original logging plan established by the company, confuses the general analysis on the evaluation of "sustainable management", as mentioned by Braz et al. (2014). Even if it were possible to reduce it, this long cycle would be necessary only if no proper structure we set aside. If planned option is applied, the volume recovery would happen in a 30 -year cycle. There is also the question of whether a high "full production" would influence the mortality of smaller classes and reduce its increment, causing or increasing an imbalanced distribution. Thus, in such a situation, by withdrawing the very old trees and providing a canopy reduction would be beneficial for the young saplings. For O’Hara (1998), a high number of small 
trees is usually justified due to the expectation of high mortality in these smaller classes. However, mortality in smaller classes is due to high levels of competition within the class. O'Hara (1996) states that there is not only one sustainable structure for a specific forest type and alternative growing stock combinations and arrangements may be, likewise, sustainable, but at different levels of productivity.

There were quite an approximation between the simulations and the system from Durrieu de Madron \& Forni (1997). Only at site 3 there was a distinguished difference, which was probably due to the simulations that consider volumes and because the system from Durrieu de Madron and Forni only considered the number of stems that could reach the commercial classes without specifying which classes and final volume to which they corresponded. However, the system was effective to rapidly identify the recovery potential for the next cycle.

Without adjusting the management plan, considering the remnant forest structure for the next cycle, it is unlike that it might present a high recovery. Thus, if the research on species individually or on groups of species are compared, the recovery volume values (according to the logging planned by the company) estimated for sites 1 and 3 (51 and 31\% of useful volume, respectively), are consistent with several studies that evaluated recovery after logging in Amazonia: Alder \& Silva (2001), while simulating the recovery volume at 30-year cycles, they found between 39 and $55 \%$ of commercial volume available; Azevedo et al. (2008), while using the SYMFLOR simulation model (Framework for Modelling the Effects of Silviculture on the Growth and Yield of Tropical Forests), identified that the mean annual increment $(A A I)$ should be on average $35.5 \%$ of the total AAI removed, for a 30 -year cycle; Van Gardingen et al. (2006) calculated 33\% as limit for yield to be no more than $33 \%$ of standing commercial volume, also for a cycle of 30 years; to guarantee $100 \%$ recover of the volume logged, Braz et al. (2012a) identified three cutting rates for commercial grades: $24.4 \%, 35.4 \%$ and $42.4 \%$ for a group of 26 species and Sist et al. (2007) emphasized that even when using low impact management, only $50 \%$ of the commercial timber would be recovered.

The recovery volume in the three sites gives emphasis to the statement that timber production sustainability depends on planning. Moreover, the excellent recovery volume observed at site 2 results from the outstanding stock in very productive diameter classes. These results modify the expectations of timber forest management.

On the other hand, the inclusion of the concept of "maximum expected volume" makes the prediction more realistic, because it only considers classes that actually "contribute to producing commercial timber volume". The erroneous expectation that after logging all volume of timber would be recovered without planning a remnant diametric structure that sustain a new cycle, has led to pessimistic predictions about forest management. For the same reason it is wrong to expect to recover the same structure as that which existed prior to the cut cycle in a production forest. Odum (1988) considers the possibility that a community grows old after reaching maturity, just as what occurs in individual organisms. To expect the exact original structure recovery would represent ignoring the "aging" of that forest community. At a certain point, the volume of a forest reaches its climax and it is not possible to increase any more, resulting in negative increment, as discussed by Osmaston (2010).

Depending on the remnant structure at a site, it would normally requires 30 years to reach the maximum diameter class of $85 \mathrm{~cm}$. From a production point of view, it is wrong to allow the trees to reach the class of $95 \mathrm{~cm}$ or above. Braz et al. (2012b) in the state of Amazonas also found, for a group of 26 commercial species, that the $85 \mathrm{~cm}$ of DBH class was the diameter limit of trees to produce surplus volume for a second cycle. Proposals to increase the cut cycle indefinitely, aiming to recover the extracted volume for any tree species, are the result of technical misinterpretation of data when considering a timber production forest. However, this does not mean that the trees in diameter classes above $95 \mathrm{~cm}$ need to be eliminated, as many of them have ecological importance to the ecosystem. Moreover, from a logging company's point of view, many large trees need to be set aside in the forest because they already present hollowed or rotten trunks.

There is confusion between timber production and its sustainability with ecological sustainability. Timber sustainability concerns the company's management requirements regarding the timber stock, and mostly the economic viability of the second cycle, or even later cycles, that could be planned at the logged sites. Ecological sustainability concerns the balance to be maintained in a stable manner in areas where there is no logging activity being carried out. 
The maps presenting the trees distribution in the three sites (Figures 6,7 and 8) confirm that the remnant structures are consistent. At all three sites, there were no clear cut of $C$. odorata trees above the commercial diameter limit.

From the spatial structure, it is possible to verify that C. odorata trees present a tendency to be grouped and the weight of the trees in the PPAs have a great influence on the forest structure, resulting in a density above the remnant amount that is usually considered (only $10 \%$ of the allowable cut limit). Extractions of $90 \%$ above the limit of $50 \mathrm{~cm}$ do not occur or are very seldom used in forest companies. It should also be considered that these sites are part of the forest and that they are not necessarily inserted in fragmented areas but they are surrounded by primary forests. The genetic simulation that does not consider these criteria certainly causes misunderstandings.

Thus, the PPAs trees and logging remnants will play a part in the pollination of the forest system as a whole. The mean distances between trees remain within a reasonable distance (maximum $143 \mathrm{~m}$ ). Sebben et al. (2007) report between 800 and $3,500 \mathrm{~m}$ as the "maximum flight distance pollination". Thus, it is questionable that "all" good quality trees above the minimum allowable logging diameter are extracted, thereby causing the depletion of valuable species, as was also mentioned by Zimmerman $\&$ Kormos (2012). Many researches far from the companies logging reality, and that were only carried out within experimental areas can spread equivocate information throughout Amazonia.

It should be noted that in other systems, such as in agriculture, different from the management investigated here, can result in the complete extinction of forest in the productive area, despite PPAs and law restrictions concerning clear cut areas being preserved, as a legal requirement.

Considering that: a) the structures are in different stages, according to their growth stage, with no definite pattern; b) that there may only be an expected economic return up to $85 \mathrm{~cm}$ of $\mathrm{DBH}$, and that the further classes present general symptoms of late maturity and senescence; c) the distance among remnant trees will not prevent pollination; and d) because it is fundamentally a "production forest", there is no reason to demand that the forest should return to the original structure within the cutting cycle after its exploitation. What should be desirable is that the forest have a similar production to the original in the following cycles. So, beyond the adequate remnant forest structure, silvicultural treatments must be considered, as future timber yields can be enhanced using those procedures after exploitation (Putz et al., 2012). Nevertheless, reduced impact logging would also improve Amazon forest management, although it has yet to be correctly assimilated by local forest managers.

\section{Conclusions}

Different from most studies and analysis in the Brazilian Amazon region, the forest companies usually do not cut all commercial stock or a value as high as $90 \%$ of the commercial stock in a management plan, even when individually considering a species.

To assess if one management plan will be sustainable, it is necessary to evaluate the stock differences, productive $\mathrm{DBH}$ classes and its growth according to the specific site's characteristics.

A large number of trees are set aside in PPAs as remnant trees for the next cycle. These trees play a role in the pollination of the system and also influence the management sustainability.

The concept of "maximum expected volume" is more realistic and should be included in discussions regarding the management of natural tropical production forests. Nevertheless, it is not necessary to recover the original forest structure to configure "sustainability", which is mainly because the original structures do not have a unique pattern and may be at different stages of development. The remnant forest structure, in terms of its logged and in stock volume, greatly affects the recovery volume for the next cutting cycle. On the other hand, the structures vary greatly at each site.

It is very important to plan the remnant forest structure when aiming at higher future production, and in this case, the differential increment by diameter class plays a decisive role.

The procedure of adjusting the number of remnant trees and classes, aiming at a second cycle, and simplifying the simulations can give very informative predictions about the future potential and can be easily communicated to the decision makers of the companies in order to enrich arguments for their best interest that are so far very limited.

Management planning with these concepts will be useful to forest managers and is the key to ensuring 
truly sustainable management. For this to materialize, there should be greater flexibility of forestry legislation.

\section{References}

ACRE. Governo do Estado. Programa Estadual de Zoneamento Ecológico-Econômico do Acre. Zoneamento ecológico-econômico do Acre fase II: documento síntese. escala 1:250.000. Rio Branco, AC: Secretaria de Estado de Planejamento e Desenvolvimento Econômico Sustentável, 2006. 354 p.

ALDER, D. Growth modelling for mixed tropical forests. Oxford: Oxford Forestry Institute, Department of Plant Sciences, University of Oxford, 1995. $231 \mathrm{p}$.

ALDER, D.; SILVA, J. N. M. Sustentabilidade da produção volumétrica: um estudo de caso na Floresta nacional de Tapajós com auxílio do modelo de crescimento CAFOGROM. In: SILVA, J. N. M.; CARVALHO, J. O. P. de; YARED, J. A. C. (Ed.). A silvicultura na Amazônia Oriental: contribuições do projeto Embrapa-DFID. Belém: Embrapa Amazônia Oriental: DFID, 2001. p. 325-337.

ALDER, D. Simple methods for calculating minimum diameter and sustainable yield in mixed tropical forest. In: MILLER, F.M.; ADAM, K. L. Wise management of tropical forests: proceedings of the Oxford Conference on Tropical Forests 1992, held in the University Museum, Parks Road, Oxford 30 March-1 April 1992. Oxford: Oxford Forest Institute, 1992. p. 189-200.

AMARO, M. A. Análise da participação da Seringueira (Hevea brasiliensis), Castanheira (Bertholletia excelsa) e das principais espécies madeireiras na estrutura da floresta, no trecho Rio Branco-Cruzeiro do Sul (AC) da BR 364. 1996. 78 f. Dissertação (Mestrado em Ciências de Florestas Tropicais) - Instituto Nacional de Pesquisas da Amazônia, Manaus.

ASSMANN, E. The principles of Forest Yeld Study: studies in the organic production, structure, increment and yield of forests stands. Oxford: Pergamon Press, 1970. p. 481-484.

AZEVEDO, C. P.; SANQUETTA, C. R.; SILVA, J. N. M.; MACHADO, S. A.; SOUZA, S. R.; OLIVEIRA, M. M. de. Simulação de estratégias de manejo florestal na Amazônia com o uso do modelo SYMFOR. Acta Amazonica, Manaus, v. 38, n. 1, p. 51-70, 2008. DOI: $10.1590 / \mathrm{S} 0044-59672008000100007$.

BRAZ, E. M.; MATTOS, P. P. de; FIGUEIREDO, E. O.; RIBAS, L. A. Otimização da distribuição diamétrica remanescente da espécie Cedrela odorata no estado do Acre, visando o novo ciclo In: SIMPÓSIO LATINO-AMERICANO SOBRE MANEJO FLORESTAL, 5., 2011, Santa Maria, RS. Sustentabilidade florestal: [anais]. Santa Maria, RS: UFSM, Programa de Pós-Graduação em Engenharia Florestal, 2011. p. 183-193.

BRAZ, E. M.; MATTOS, P. P. de; OLIVEIRA, M. F.; BASSO, R. O. Strategies for achieving sustainable logging rate in the Brazilian Amazon Forest. Open Journal of Forestry, v. 4, n. 2, p. 100-105, 2014. DOI: $10.4236 /$ ojf.2014.42015

BRAZ, E. M.; SCHNEIDER, P. R.; MATTOS, P. P. de; SELLE, G. L.; THAINES, F.; RIBAS, L. A.; VUADEN, E. Taxa de corte sustentável para manejo de florestas tropicais. Ciência Florestal, Santa Maria, RS, v. 22, n. 1, p. 137-145, 2012a. DOI: 10.5902/198050985086
BRAZ, E. M.; SCHNEIDER, P. R.; MATTOS, P. P. de; THAINES, F.; SELLE, G. L.; DE OLIVEIRA, M. F.; OLIVEIRA, L. C. Manejo da estrutura diamétrica remanescente de florestas tropicais. Ciência Florestal, Santa Maria, RS, v. 22, n. 4, p. 787-794, 2012b. DOI: 10.5902/198050987559

BRAZ, E. M. Subsídios para o planejamento do manejo de florestas tropicais da Amazônia. 2010. 236 f. Tese (Doutorado em Engenharia Florestal) - Universidade Federal de Santa Maria, Santa Maria, RS.

BRIENEN, R. J. W.; ZUIDEMA, P. A. Lifetime growth patterns and ages of Bolivian rain forest trees obtained by tree ring analysis. Journal of Ecology, Oxford, n. 94, p. 481-493, 2006a. DOI: 10.1111/j.1365-2745.2005.01080.x

BRIENEN, R. J. W.; ZUIDEMA, P. A. The use of tree rings in tropical forest management: projecting timber yields of four Bolivian tree species. Forest Ecology and Management, Amsterdam, n. 226, p. 256-267, 2006b. DOI:10.1016/j.foreco.2006.01.038

CLUTTER, J. L. Forest Management opportunities for the future. In: BROWN, K. M.; CLARKE, F. R. (Ed.). Proceedings of Workshop held at School of Forestry, Lakehead University, Thunder Bay. Ontario: School of Forestry, Lakehead University, 1980. p. 246-255.

CUNHA, T. A. da; FINGER, C. A. G. Asymmetric competition and the diameter increment of Cedrela odorata L. trees in western Amazonia. Acta Amazonica, Manaus, v. 43, n. 1, p. 9-18, 2013. DOI:10.1590/S0044-59672013000100002

DURRIEU DE MADRON, L.; FORNI, E. Aménagement forestier dans l'Est du Cameroun: structure du peuplement et périodicité d'exploitation. Bois et forêts des tropiques, n. 254, p. 39-50, 1997.

EK, A. R.; MONSERUD, R. A. Performance and comparison of stand growth models based on individual tree and diameter class growth. Canadian Journal of Forest Research, Ottawa, n. 9, p. 231-244, 1979. DOI: $10.1139 / \times 79-040$

FINGER, C. A. G. Fundamentos da biometria florestal. Santa Maria, RS: UFSM/CEPEF-FATEC, 1992. 108 p.

ODUM, E. P. Ecologia. Rio de Janeiro: Guanabara, 1988. 434 p.

OLIVEIRA, M. V. N. D'. Simulação de crescimento, rendimento e corte seletivo para o manejo florestal sustentado em pequenas propriedades no Estado do Acre, na Amazônia Brasileira. In: GONÇALVES, R. C.; OLIVEIRA, L. C. de (Ed.). Ciência e tecnologia para o desenvolvimento sustentável do sudoeste da Amazônia. Rio Branco, AC: Embrapa Acre, 2009. p. 39-67.

O'HARA, K. L. Dynamics and stocking-level relationships of multiaged ponderosa pine stands. Forestry Science, v. 42, n. 4, p. 1-12, 1996. (Monograph, 33).

O'HARA, K. L. Silviculture for structure diversity: a new look at multiaged systems. Journal of Forestry, Washington, US, v. 96, n. 7, p. 4-10, 1998.

OSMASTON, F. C. The actual growing stock and its increment. In: OSMASTON, F. C. The management of forests. Dehradun: Natraj, 2010. p. 147-148.

PORTÉ, A.; BARTELINK, H. H. Modeling mixed forest growth: a review of models for forest management. Ecological Modeling, n. 150 , p. 141-188, 2002. DOI: 10.1016/S0304-3800(01)00476-8 
PUTZ, F. E.; DYKSTRA, D. P.; HEINRICH, R. Why poor logging practices persist in the tropics. Conservation Biology, Boston, v. 14, n. 4, p. 951-956, 2000.

PUTZ, F. E.; ZUIDEMA, P. A.; SYNNOTT, T.; PEÑA-CLAROS, M.; PINARD, M. A.; SHEIL, D.; VANCLAY, J. K.; SIST, P.; GOURLETFLEURY, S.; GRISCOM, B.; PALMER, J.; ZAGT, R. Sustaining conservation values in selectively logged tropical forests: the attained and the attainable. Conservation Letters, n. 5, p. 296-303, 2012. DOI: 10.1111/j.1755-263X.2012.00242.x

SCHÖNGART, J. Growth-Oriented Logging (GOL): a new concept towards sustainable forest management in Central Amazonian varzea floodplains. Forest Ecology and Management, Amsterdam, n. 256, p. 46-58, 2008. DOI:10.1016/j.foreco.2008.03.037

SCOLFORO, J. R. S. Manejo florestal. Lavras: UFV, FEPE, 1998. $443 \mathrm{p}$.

SEBBENN, A.; DEGEN, B.; AZEVEDO, V. C. R.; SILVA, M. B.; LACERDA, A. E. B.; CIAMPI, A. Y.; KANASHIRO, M.; CARNEIRO, F. da S.; THOMPSON, I.; LOVELESS, M. D. Modeling the long-term impacts of selective logging on genetic diversity and demographic structure of four tropical tree species in the Amazon forest. Forest Ecology and Management, Amsterdam, n. 254 , p. $335-339$, 2008. DOI: 10.1016/j.foreco.2007.08.009
SILVA, J. N. M.; SILVA, S. M. A.; COSTA, D. H. M.; BAIMA, A. M. V.; OLIVEIRA, L. C.; CARVALHO, J. O. P.; LOPES, J. C. A. Crescimento, mortalidade e recrutamento em florestas de terra firme da Amazônia Oriental: observações nas regiões do Tapajós e Jari. In: SILVA, J. N. M.; CARVALHO, J. O. P. de; YARED, J. A. C. (Ed.). A silvicultura na Amazônia Oriental: contribuições do projeto Embrapa-DFID. Belém: Embrapa Amazônia Oriental: DFID,2001. p. 291-305.

SIST, P.; FERREIRA, F. N. Sustainability of reduced-impact logging in the Eastern Amazon. Forest Ecology and Management, Amsterdam, n. 243, p. 199-209, 2007. DOI:10.1016/j.foreco.2007.02.014

VANCLAY, J. K. Modeling forest growth and yield applications to mixed tropical forests. Utah: Walling-Ford, 1994. 104 p.

VAN GARDINGEN, P. R.; VALLE, D.; THOMPSON, I. Evaluation of yield regulation options for primary forest in Tapajo's National Forest, Brazil. Forest Ecology and Management, Amsterdam, n. 231, p. 184-195, 2006. DOI:10.1016/j.foreco.2006.05.047

ZIMMERMAN, B. L.; KORMOS, C. F. Prospects for sustainable logging in tropical forests. BioScience, Washington, US, n. 62, p. 479-487, 2012. DOI:10.1525/bio.2012.62.5.9 
